COBISS: 1.01

\title{
SCHAFFENRATH'S INSCRIPTION COLUMN IN PISANI ROV, POSTOJNSKA JAMA
}

\section{SCHAFFENRATHOV NAPIS NA KAPNIŠKEM STEBRU V PISANEM ROVU POSTOJNSKE JAME}

S. KEMPE \& I. BAUER \& H. DIRKS ${ }^{1} \&$ H.-V. HENSCHEL ${ }^{2}$

${ }^{1}$ Prof. Dr. Stephan Kempe, stud geol. Ingo Bauer, stud geol. Heiko Dirks, Institute for Applied Geosciences, University of Technology Darmstadt, Schnittspahnstr. 9, D-64287 Darmstadt, Germany, email: kempe@geo.tudarmstadt.de

${ }^{2}$ Dr. Horst-Volker Henschel, Henschel \& Ropertz, Am Markt 2, D-64287 Darmstadt, email: dr.henschel@henschelropertz.de 
Kempe, S. \& I. Bauer \& H. Dirks \& H.-V. Henschel: Schaffenrath's Inscription Column in Pisani rov, Postojnska jama

Inscriptions may help to clarify the incompletely documented early history of the discovery of the main passages in Postojnska jama. This period is associated with three people: Josef (Josip) Jeršinovič Ritter von Löwengreif, Alois Schaffenrath, and Franz Graf von Hohenwart. Based on the contemporary writings of Schaffenrath (1834), Hohenwart (1830, 1832a,b) and Schmidl (1854) the authors discuss the circumstances and timing of the exploration of the main cave, suggesting that the main passage was not discovered until after the visit of Erzherzog Ferdinand in August 1819. One of the earliest inscriptions from that period is found on a column in Pisani rov, $90 \mathrm{~m}$ from its branch from the main passage. Here Schaffenrath left in 1825 the names of Löwengreif, of Gospodaritsch, and of himself. This column may be the only site in Postojnska jama featuring all three names in one place. In view of the rather late exploration of the main passage, the date 1825 may be the discovery date of this section of the cave since it does not appear on the earliest map published (Bronn, 1826, based on a map of Foÿker/Schaffenrath ca. 1821). In 1832 the back part of Pisani rov was opened and named in honour of Erzherzog Johann. Several more inscriptions were placed on the column. Further down the passage a few more inscriptions exist. One was dated 1836 by J(ozef) Hauer, a paleontologist and the father of Franz Ritter von Hauer. Also Anton Perko, the younger brother of Ivan Andrej Perko left his name. I.A. Perko signed as well, but in the Rov brez imena, in the year 1892, a year before he, his brother and others founded the student cavers' club "Hades" in Trieste. Search and documentation of historic inscriptions may therefore aid in reconstructing the exploration and visitation history of this most important show cave.

Key Words: history of speleology, show cave history, Postojnska jama discovery, Slovenia.

\section{Izvleček}

UDK:551.442(497.4 Postojna)

\section{Kempe, S. \& I. Bauer \& H. Dirks \& H.-V. Henschel: Schaffenrathov napis na kapniškem stebru v Pisanem rovu Postojnske jame}

Napisi lahko pripomorejo k razjasnitvi nezadostno dokumentirane zgodovine odkrivanja glavnih rovov Postojnske jame. Ta čas je bil povezan s tremi osebami: Josipom Jeršinovičem plemenitim Löwengreif, Alojzom Schaffenrathom in grofom Francem Hohenwartom. Temelječ na sodobnih zapisih Schaffenratha (1834), Hohenwarta (1830, 1832a,b) in Schmidla (1854), avtorji razpravljajo o okoliščinah in času njihovih raziskovanj glavne jame ter menijo, da ta ni bila odkrita do prihoda nadvojvode Ferdinanda avgusta 1819. Eden najstarejših napisov iz tega časa je na kapniškem stebru v Pisanem rovu, $90 \mathrm{~m}$ od tam, kjer se odcepi od glavnega rova. Tu je Schaffenrath 1825 zapisal imeni Löwengreifa, Gospodaritscha in svoje. Ta steber je morda edino mesto v Postojnski jami, kjer so vsa tri imena skupaj. Če upoštevamo razmeroma pozne raziskave glavnega rova, je letnica 1825 morda leto odkritja tega dela jame. To potrjuje tudi dejstvo, da tega dela jame ni na prvem objavljenem zemljevidu (Bronn, 1826, temelječ na zemljevidu Foÿker/Schaffenrath iz okoli 1821). 1832 je bil odprt notranji del Pisanega rova in imenovan v čast nadvojvode Janeza. Na steber so dodali še več napisov, več pa jih je tudi dalje po rovu. Iz 1836 je podpis J(ozef) Hauer, to je paleontolog in oče Franca plemenitega Hauerja. Tudi Anton Perko, mlajši brat Ivana Andreja, je zapustil svoje ime. I.A. Perko je podpisan 1892 v Rovu brez imena, v letu preden so on, njegov brat in drugi v Trstu ustanovili študentsko jamarsko društvo "Hades". Raziskovanje in dokumentiranje zgodovinskih napisov lahko pomaga pri rekonstrukciji in razlagi zgodovine raziskav in odkrivanj te najpomembnejše turistične jame.

Ključne besede: zgodovina speleologije, zgodovina turistične jame, Postojnska jama - odkritje, Slovenija. 


\section{INTRODUCTION}

The historic importance of Postojnska jama, alias Adelsberger Grotte, for the public and for cave science in the early 19th century cannot be overstressed. At the time of the incidental discovery of the entrance to the cave on (date according to Habe, 1968) 14 April 1818, by Luka Čeč (Lukas Tschesch in the German spelling), a local cave guide (1785-1836), not many caves were accessible to the public in Europe; and none provided such a variety of speleothems. The rapid development of the new discoveries as a show cave was an achievement which must be largely attributed to a few people, primarily to the district treasurer Josef (Josip) Jeršinovič Ritter von Löwengreif (1775-1847), the engineer Alois Schaffenrath (1794-1836) and the author and district governor Franz Graf von Hohenwart (1777-1844). It is therefore interesting to report an inscription column which carries the names of all three of them dating from the early days of the Postojnska jama operation.

\section{PISANI ROV (ERZHERZOG JOHANN GROTTE)}

The history of the discovery of the main part of Postojnska jama (PJ) and therefore of Pisani rov begins in the year 1816 when Emperor Franz I (1768-1835) travelled to Trieste and wanted to visit the old Adelsberger Grotte en passant. Since the Old Dome (Veliki dom) never had been adequately illuminated, Löwengreif took the initiative and had people descend to the river to fix lights (Schmidl, 1854, p. 14). It was then that he discovered that the river, formerly considered to be deep and dangerous, was only a few feet deep; and Löwengreif had people crossing it to place lights on the other side as well. When Franz I visited the cave on 16 May 1816, the Dome was illuminated in almost all its complete expanse for the first time in history. What happened next is much debated in the respective publications (e.g., Habe, 1968; Shaw, 1992). Schmidl (1854, p.16-17) reproduced a statement signed by Jacob Widmar on 19 December 1823, which says that the initial climb up the far side of the Dome, and the subsequent discovery of the new passages by Čeč, was done in April 1818 due to the pending visit of Franz I. Widmar says that Čeč stayed away for about half an hour and that those staying behind saw his light fading. Čeč therefore must have been into the passage for about $100 \mathrm{~m}$. On the next day, Widmar, Franz Mühleisen, Jakob Vitschitsch, Franz Schibenig and Tschesch returned and explored the new passage. They did not take the path into the large „Grottengang“ towards the „Turniersaal”, but the one which led to the later Ferdinands Grotte. Schmidl (1854, footnote p.17) made clear that these passages were the ones now occupied by the biological station. He says: "Damit ist der Seitengang No. 1 gemeint, welchen Kaiser Ferdinand zuerst betrat, der Hauptgang wurde nämlich erst nach der Hand entdeckt." (i.e.. "This refers to the side passage No. 1 which was entered first by Emperor Ferdinand because the main passage was discovered only afterwards"). Erzherzog Ferdinand (1793-1875) visited the cave on 17 August 1819, (he actually became emperor only in 1835). He was the first to sign the official guest book of Postojnska jama, which therefore is of no help when it comes to the early visits of Franz I (Shaw \& Čuk, 2002). In summary, it appears that the bulk of the main passages was not discovered until after the visit of Erzherzog Ferdinand, i.e. after August 1819.

Thus the order of events may have been as follows:

(i) Franz I was expected to visit the old cave in April 1816. Löwengreif had the workers descend to the river in the Large Dome. It was discovered that the river can be crossed and that lights can be placed on the far side to illuminate the Large Dome. This lighting was used to show 
Franz I the Lrgee Dome on 16 May 1816.

(ii) Not much happened for the next two years.

(iii) In April 1818, Franz I and his wife Carolina Augusta were en route to Dalmatia and wished to revisit the cave (or Löwengreif wished to display it again?). On 14 April Löwengreif had cave guide Luka Čeč and others again descend to the river, and let them cross to the far side to place lights there. Čeč discovered the access to the new passages, going in for about half an hour (i.e. no much further than $100 \mathrm{~m}$ ).

(iv) The next day the proximal part of the new passage was explored by a party without Löwengreif.

(v) Whether Franz I and the Empress entered the cave on 16 April remains unclear. The statement of Widmar (Schmidl, 1854, p. 16) says so, but the local newspaper mentions only that the Royals stayed in Postojna but not that they visited the cave (pers. com. Mrs. M. Kranjc).

(vi) The knowledge of the new passages rested until August 1819 when the announced visit of Erzherzog Ferdinand prompted renewed activity. The first section of the main passage and the proximal side passages were made accessible and named in honour of the Erzherzog.

(vii) Only afterwards do the main passage, the Tournament Hall, the access to the Calvary and the entrance to Pisani rov seem to have been discovered (for details see below). Much later the main passage in its entirety was named Kaiser Ferdinand Grotte.

The statement of Widmar is important because it explicitly mentions April 1818 and the presence of Carolina Augusta. She was the fourth wife of Franz I and married to him only since October 1816. She therefore could not have been present in April 1816 when the river was first crossed and when the discovery climb could also have been possible. Unless Widmar is wrong in these two details (misremembering the year and confusing the 1818 wife of Franz I with the one of 1816, i.e. with Maria Ludovica von Österreich), then April 1818 seems to be the month of this important discovery. However, Widmar also says that the royal pair actually visited the cave ("weil a.h. Ihre Majestät die Kaiserin vor hatte diese Grotte in hohen Augenschein zu nehmen, was auch späterhin wirklich stattgefunden hat") and that seems not to have been the case. This discredits the statement of Widmar to a certain extent. Anyway, in the light of this discussion it seems highly unlikely that Emperor Franz I had already been shown in as far as Velika Gora (Calvary) on 16 April 1818 (Shaw, 1992, p. 41). This would have been only two days after the discovery of the access to the main passage and would have meant a trip of at least 10 hours over rough cave floors, through puddles and without proper lighting, all in all not quite credible for an emperor, let alone for his wife. Also the statement that Čeč "discovered further parts of the caves as far as the Great Mountain" (Habe, 1986, p.15) is certainly incorrect.

The evidence that the main cave was not explored until the second half of the year 1819 rests on four observations. First of all, Schaffenrath himself (1834, p. 36) places the discovery of the main passage in the year 1819. Second, Hohenwart (1830) says that Löwengreif made the first wooden scaffold to facilitate the climb in the Old Dome in 1819 (Hohenwart, 1830, p.11); stone steps were laid only later. Third, the cave was gated in 1819 by the k.k. district office and for the first time a regular entrance fee of 30 Kreuzer was introduced (Schmidl, 1854, p. 18). And fourth and most importantly the earliest map of the main passage was produced by Foÿker and Schaffenrath in 1821. A copy of this map is preserved in the library of the Karst Research Institute in Postojna (pers. com. Mrs. M. Kranjc). It is titled: ”Situations Plan. Zur Darstellung der Berggegend, mit dem im 


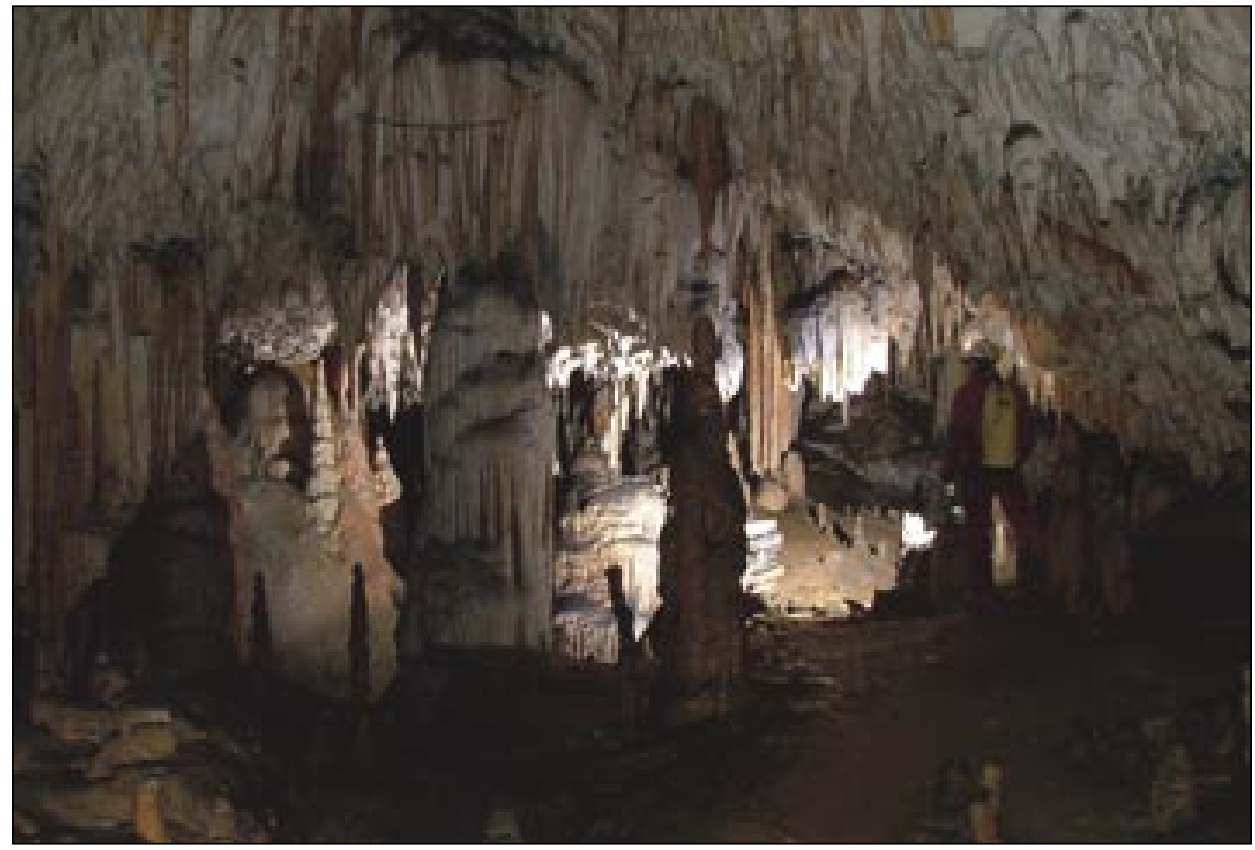

Fig. 1: View of Pisani rov $90 \mathrm{~m}$ from its entrance looking $N$. The inscription column is to the left.

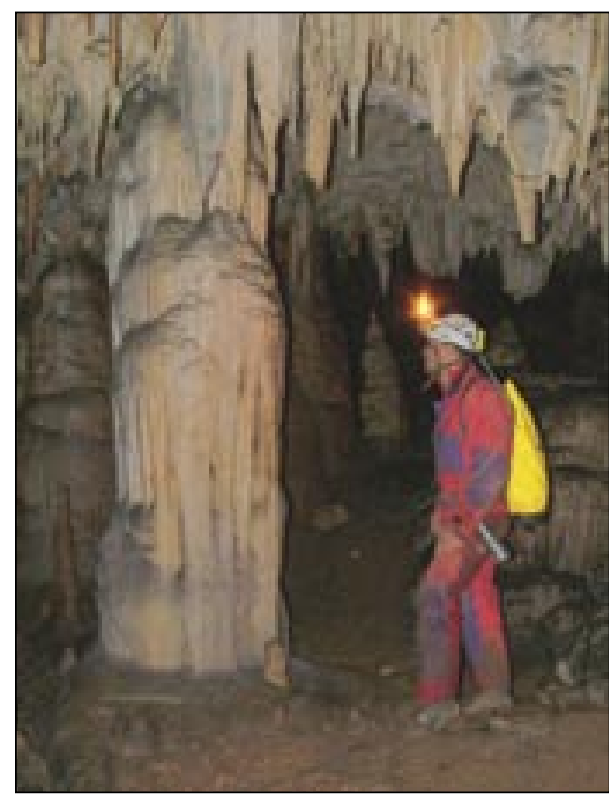

Fig. 2: Close-up of the inscription column in Pisani rov.

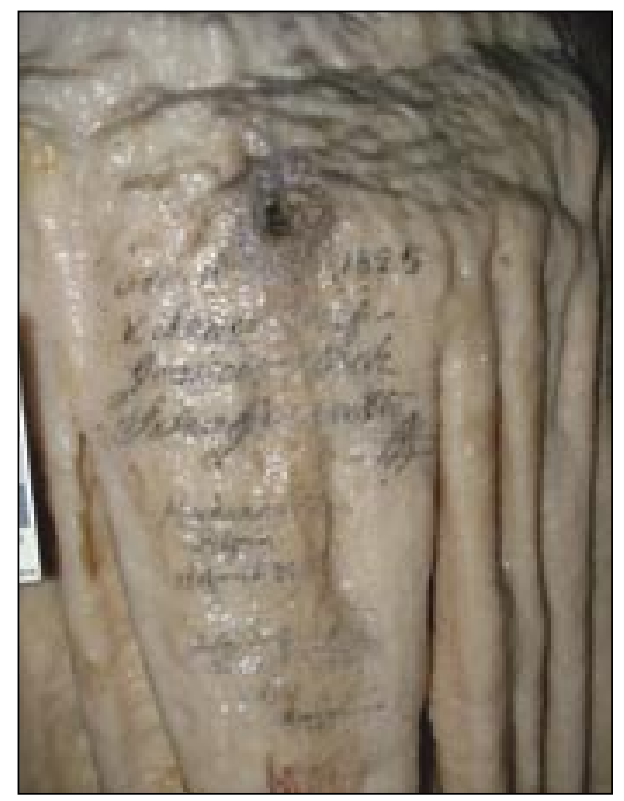

Fig. 3: The main inscription panel with the candle peg on top. 


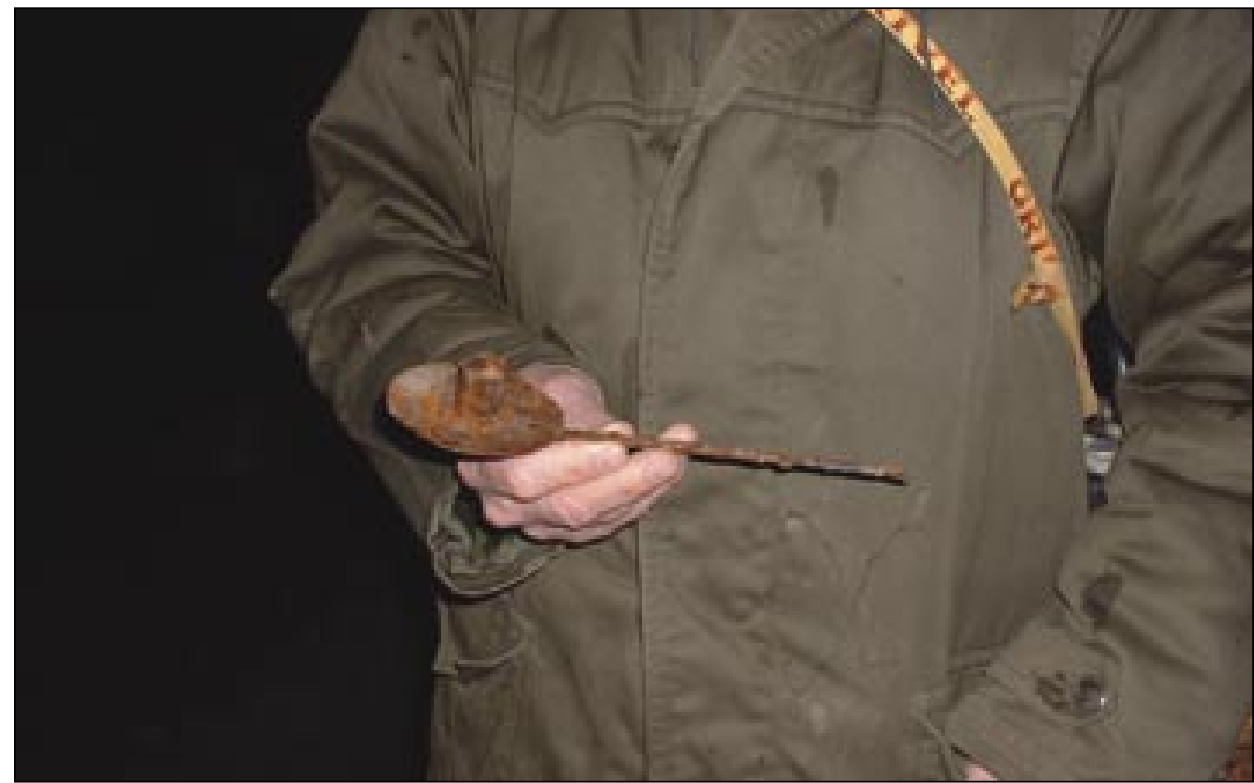

Fig. 4: A picture of one of the candle holders which used to be attached to the wooden pegs to hold candles for illumination in the early days of the show cave operation.

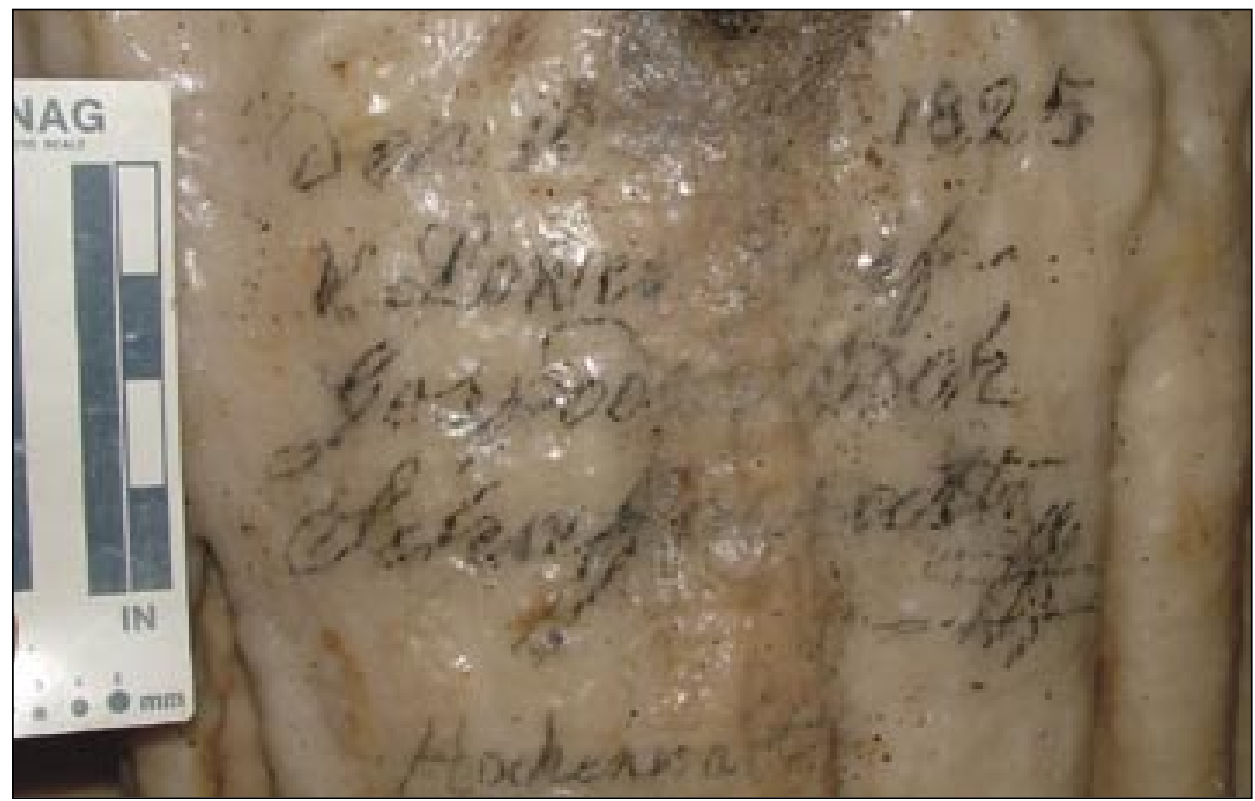

Fig. 5: A close-up of the Schaffenrath inscription of 1825 showing the names von v. Löwengreif, Gospodaritsch and Schaffenrath followed by an artistic signature of Schaffenrath, most probably an abstracted "SFF". 
Jahre 1819 neu entdecten unterirdischen Grottengange, aufgenohmen vom Sim. Foüker k.k. Strassen Comissärs Substituten; dann reducirt und hiezu mehrere innere Ansichten dieser Grotte im Jahre 1821 aufgenohmen vom Aloys Schaffenrath k.k. prov. Amtszeichner." The statement here is quite clear: the main passage ("Grottengang") was discovered in 1819 and not earlier. The survey was made by a certain Sim(on) (?) Foÿker - apparently a road surveyor - and the map was reduced by Schaffenrath. This map, a hand-coloured copperplate, may have been sold at the cave because the paleontologist Heinrich G. Bronn, who visited the cave in December 1824, cited this Foÿker-Schaffenrath map as the basis for his small sketch map which he published in 1826 to accompany his description of the cave. Actually the Bronn-map is the earliest published of Postojnska jama. Neither it nor the original Foÿker-Schaffenrath map (pers. com. Mrs. M. Kranjc) show side passages. Pisani rov may therefore have been discovered later than 1821. The map which Hohenwart published in 1830 (his Plate 1) does, however, show side passages, even though only as dotted lines and not in the full length of the actual galleries. One branch to the west at "the Grave" is today called Male jama; and two branches to the east of "the Grave", are today called Rov brez imena - Nameless Passage - and Pisani rov - Colorful Passage. The Hohenwart map is attributed entirely to Schaffenrath but appears to be simply a copy of the Foÿker map with the newly discovered passages added as sketches.

To the early explorer Pisani rov was accessible up to a clay choke beyond PJ survey point XI. Schaffenrath (1834) reports that in preparation for the visit of Erzherzog Johann in 1832 a 2 foot $(0.6 \mathrm{~m})$ high and 4 Klafter $(7 \mathrm{~m})$ long passage was discovered which led into a "wonderful, reddish reflecting grotto". This new section was shown to "Seine kaiserl. königl. Hoheit" Erzherzog Johann on 31 June 1832. He was the first foreigner in this cave as stated by Schaffenrath. The choke apparently was dug through on this occasion; it still forms one of the lowest places along the path. In consequence of this visit this section was originally called Erzherzog Johanns Grotte. Schaffenrath reports that it was closed by a gate (now defunct) at its beginning and that the key was kept by the k.k. district commander "to keep the beautiful stalactites from being damaged" (p. 30). Only very important persons were allowed in. Just behind the gate on the right-hand side a basin was used to keep a few Protei imported from the Magdalena jama. Schaffenrath praises the passage as follows: "Nowhere else in the (Adelsberger) Grotte there are so variable forms of crystallization on floor, walls, and ceiling united to form a beautiful entity and which are accessible so easily, and nowhere else has the natural scientist such a fine opportunity to study their slow formation and their transitions than here...”. Schaffenrath's description (1834, p. 32) also makes clear that the back hall (Bela Dvorana) was already known: "A small opening, accessible only by a cumbersome climb, through which one must crawl leads to the last part of this side grotto; it is a roomy hall, with many, partly erect, partly precipitated columns; its distinct ornaments are several translucent drapes of white crystals with 8 to 10 rows of darker and light-red stripes along the edges." In contrast to this vivid description is Hohenwart's report of this side passage (published in 1832b) rather short and dull. He could not see anything of interest apart from three "columns with hieroglyphic bas-reliefs" (which we cannot identify as yet). He may not have visited the little passages leading eastward behind the inscription column which features a very interesting leaning stalagmite, broken at two places, similar to the famous Schaffenrath Broken Pyramid in the main passage, about which Hohenwart (1832a) had written at length (Kempe \& Henschel, 2004).

Schaffenrath reports $(1834$, p. 36$)$ that a total of 210 Klafter $(1$ Wiener Klafter $=1,896$ m; i.e. ca. $400 \mathrm{~m}$ ) of paths had been constructed in this passage. They still serve their purpose up to PJ survey point XVII. The total length of the passage with all its "bends, branches and fissures" is 
given as 340 Klafter (ca. $645 \mathrm{~m}$ ). Thus all the parts of this cave gallery must have been known to Schaffenrath. For the Nameless Passage, called "Inaccessible Passage" by Schaffenrath, he gives a length of 180 Klafter (ca. $340 \mathrm{~m}$ ), suggesting that it also had been almost fully explored in 1834 . Schaffenrath (1834) also published a small lithographed map showing these side passages for the first time. It is based on a new survey, conducted in 1833 by the mining surveyor Johann Fercher (k.k. prov. Oberhutmann) from Idria on order of the Cave Administration Commission (Schmidl, 1854, p.23). This Fercher map is also the base for Schmidl's maps published in 1854 and 1858 which both show Pisani rov to its current extent.

\section{THE INSCRIPTION COLUMN}

About $90 \mathrm{~m}$ from the entrance of Pisani rov, $5.3 \mathrm{~m} \mathrm{SSW}$ of PJ survey point V (at $533.8 \mathrm{~m}$ a.s.l.) a $3 \mathrm{~m}$ high stalagmite, just touching the ceiling, is encountered (Figs. 1 and 2). It is shiny, white and actively growing in contrast to much of the older stalagmites in the background. On this column Schaffenrath "installed" a commemorative formal inscription (Fig. 3) facing E towards the path. Today the column carries eight groups of inscriptions. The panel was equipped with by one of the usual drill holes (1.7 $\mathrm{m}$ above the ground), in which a peg of wood was driven that could be used to support a metal candle holder. A search of the area did not reveal the remains of this holder, but Figure 4 gives an impression of how it must have looked. We found only an oxidised piece of copper or brass wire with a sling on the ground. Whether it was related to the activity at the column is unclear, but we left it in front of the inscription on the floor. The candle peg hole marked the site as a point of interest and must have given the column, when properly lit, the air of a small monument to the early visitors. We did not see any other candle peg, in the passage. Below the candle peg on the column, Schaffenrath inscribed three names in his bold and large handwriting. The colour and thickness of the lines suggest that he used a carbon pencil, such as for sketching. He topped the names with a date and ended it with his signature (Fig. 5). The inscription $(20 \times 14 \mathrm{~cm})$ reads: “

den $10 . . . . . . .1825$
v. Löwengreif
Gospodaritsch
Schaffenrath

\section{SFF}

New flowstone dripped across the candle peg and down the centre of the inscription panel. It obliterated the name of the month completely and part of Löwengreif's name. Nothing is known about Gospodaritsch (Slovenian name spelled German) (pers. com. Mrs. M. Kranjc). The late Rado Gospodarič had already tried to find out who his namesake was. Schaffenrath wrote all names in a rather artistic manner and his signature "SFF" looks like one of the artistically patterned wood cuts used to mark the end of 18th century papers. For comparison Schaffenrath's dark red chalk signature which he left in the Old Cave five years later is depicted in Figure 6. Here he finished the last letter with an artistic upward pointing flourish and included the abbreviation of his first name. Since Schaffenrath wrote all the names himself, it remains unclear if the thee men visited the passage together in 1825 , or if Schaffenrath intended to create a memorial to the early explorers. Schmidl states that Löwengreif resigned from the Cave Commission in 1823, frustrated because of unjust claims against him. He may well never have revisited the cave. Löwengreif has, however, left 


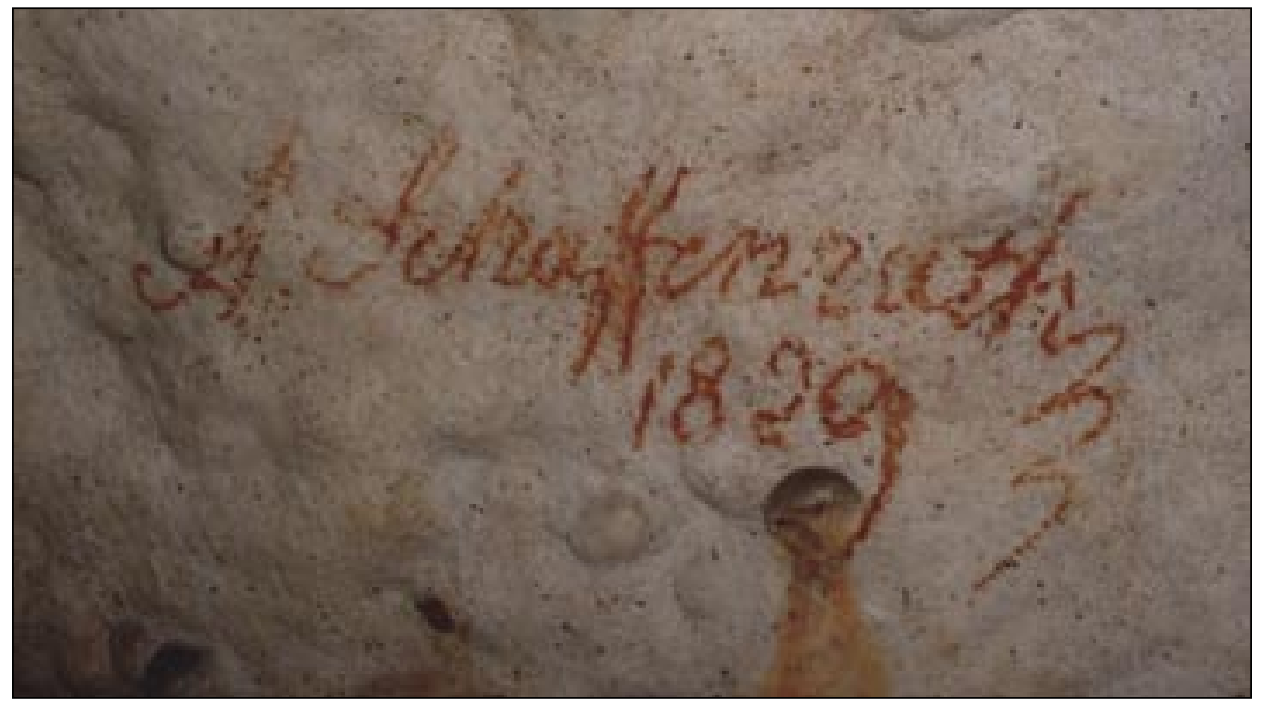

Fig. 6: Schaffenrath's signature in dark red chalk left in 1829 in the old cave.

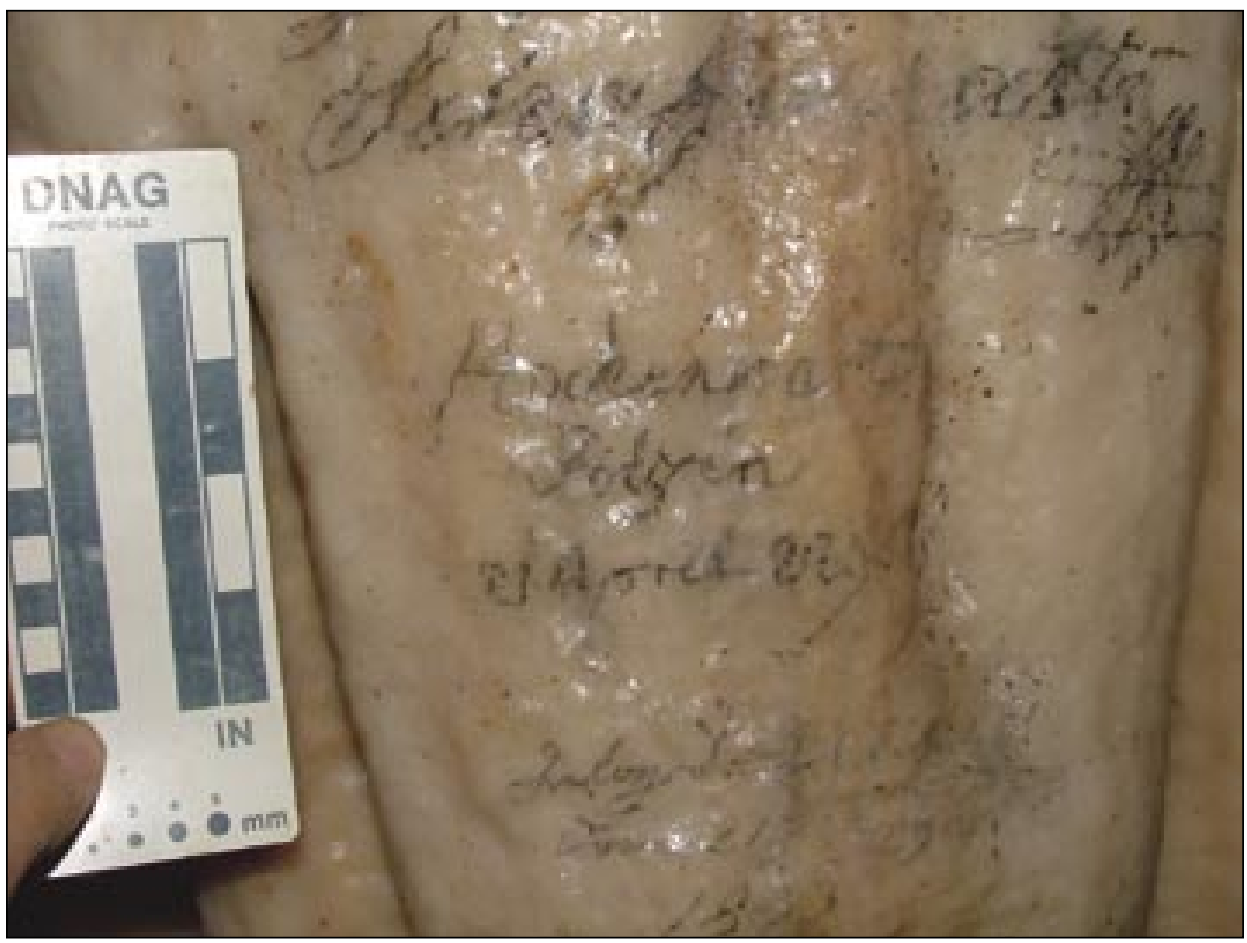

Fig. 7: Hohenwart's inscription on the column, dated 21 April 1829. Note that he spelled his name Hochenwart. Underneath there follows an illegible name with the date. 


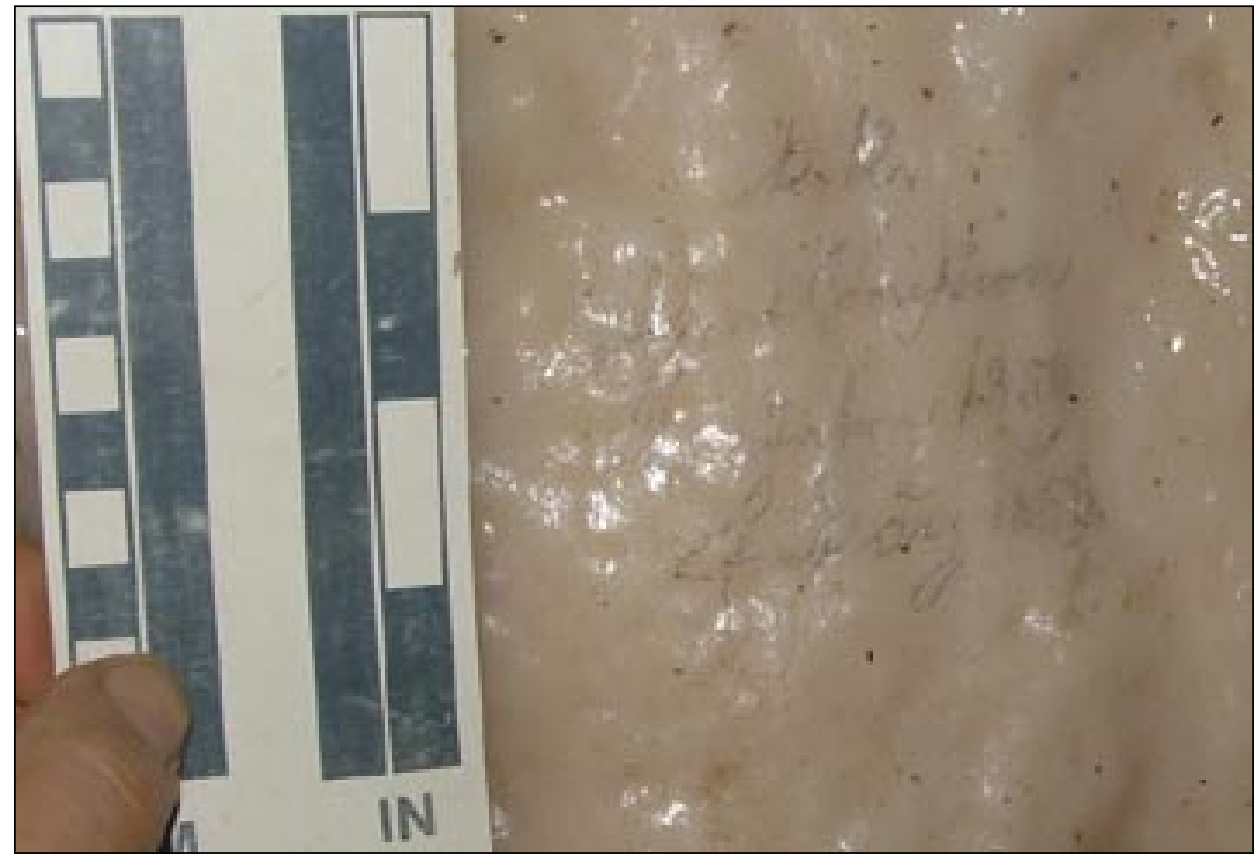

Fig. 8: The faint pencil inscription of a "k.k. Assent Commission", which visited the cave in spring 1859.

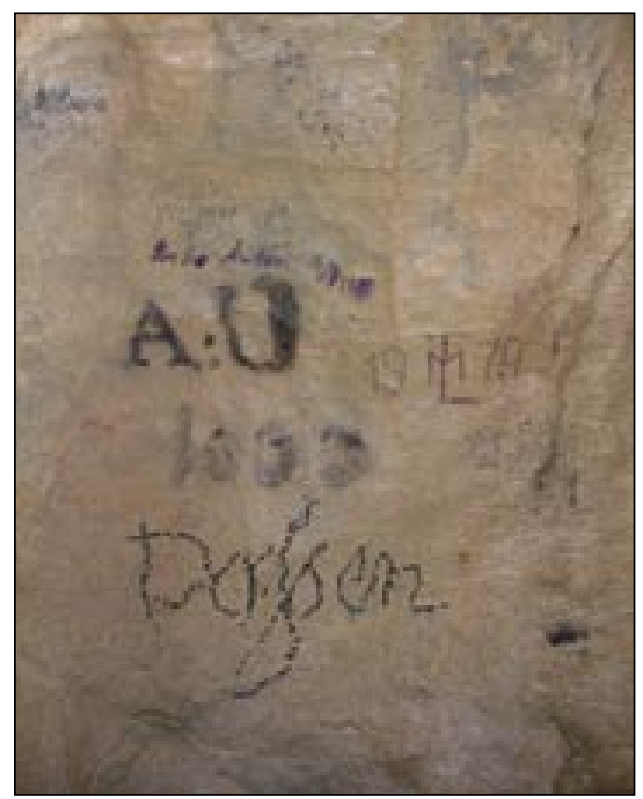

Fig. 9: The inscription panel above the path between survey stations XI and XII. inscriptions made by himself; two are found in the Old Cave dated 1814 and 1817. According to the discussion of the early maps, it is well conceivable that the entrance to Pisani rov was discovered as late as 1825 and that the date could commemorate its first exploration.

The next block (11 x $6 \mathrm{~cm}$; Fig. 7), written with a pencil, contains two names and a date:

\section{Hochenwart}

$$
\begin{gathered}
\text { Polgen (or Polgin) } \\
21 \text { April } 1829
\end{gathered}
$$

Franz von Hohenwart most probably made the signature himself since he used to sign with "Hochenwart" instead of "Hohenwart". The second name is not known to historians according to Mrs. Kranjc. Could it have been the servant of Hohenwart? Both the Schaffenrath and the Hohenwart dates predate the excavation of the continuation.

The next pencil text block (12 x $5 \mathrm{~cm}$; Fig 7 ) is almost illegible. Especially the right-hand 


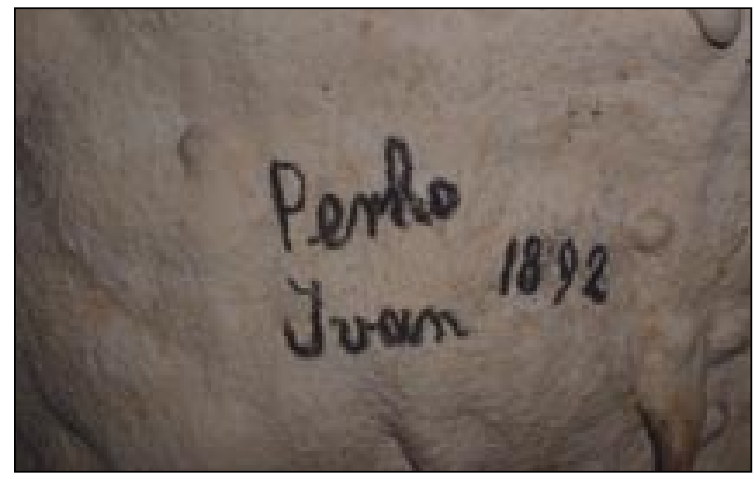

Fig. 10: The name of Iwan Perko, dated 1892, in the Rov brez imena. He was one of the founders of the caving club "Hades" in Trieste.

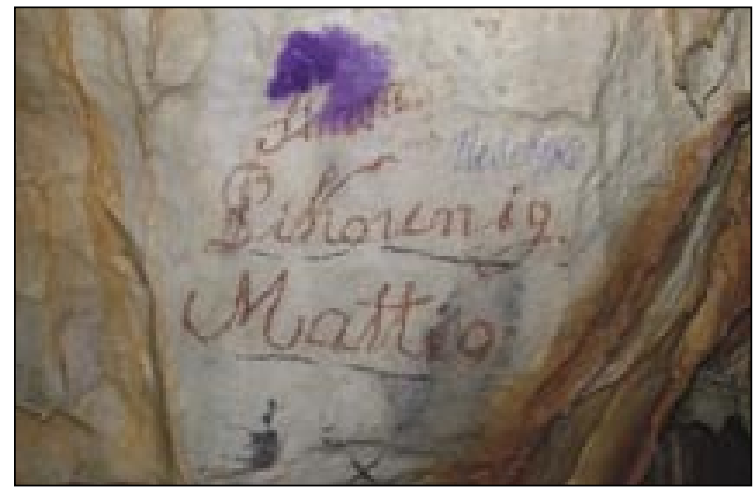

Fig. 11: A dark red chalk inscription on the W-wall shortly before survey station XII.

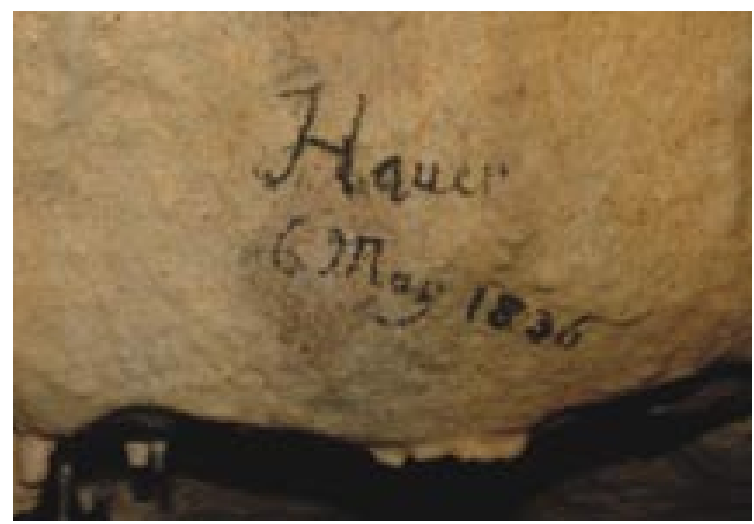

Fig. 12: The inscription of a certain "Hauer" near the same place as in Fig. 10. side of the inscription is obliterated by a thin layer of flowstone. The digital pictures taken in macromode actually allow a much better view than seen by the unaided eye in the cave since the flash can penetrate the new flowstone to a certain extent. The inscription is written in Current script, the German handwriting used in parallel to the Latin letters. According to Harald Süß (pers. com.) - a specialist of Current script - the first name can be read as "Aloys". The " $A$ " is a complex letter involving not only the "L" looking double curl but also the next smaller bulge. The end " $\mathrm{s}$ " is a flourish pointing upward as is usual in Current handwriting of the time. The following family name cannot be clearly read. A long curved underlining is however discernable. The name is followed by a date, of which we can read "den 21" (again written in Current script) and the year "1833". This is the year when a team of surveyors from Idria surveyed Postojnska jama. In the Tartarus the team, led by Johann Fercher, left their signature, dated February $7^{\text {th }}, 1833$. Among them was a certain Aloys Urbas. It is highly probable that it is also his name in Pisani rov. When looking at the pictures again, "Urbas" would fit with the pattern of lines discernable through the flowstone.

The last inscription on the front panel is the smallest $(7 \times 1 \mathrm{~cm})$ and also difficult to read. The first letters may be "Komm..." the last ones "old" or "ald". One of us suggested a name followed by "55 years old", implying an English inscription.

Below this inscription there are a few red lines. It is not clear if these 
are natural red streaks on the sinter or if they formed a rough sketch of something in red chalk. Even with a magnifying glass, we could not decide on the nature of this feature.

To the left of the main panel there is a name "Desjardins", in pencil, followed by a date "8 ja 1839 " (month unclear) (9 x 5cm).

Above, $12 \mathrm{~cm}$ left of the upper panel, is a $8 \times 6 \mathrm{~cm}$ large pencil inscription consisting of four lines (Fig. 8):

k.k.

Assent Comission

Im Jahr 1859

27. März 1859

This is an interesting signature, since it marks the visit of a "k.k.", i.e. kaiserlich-königlich Habsburgian Commission. It was most probably an "Assentierungs Commission" which had to recruit soldiers. In the year 1859, on 26 April, Habsburg declared war against the allied Piemonte and French, demanding demobilisation of Northern Italy. The terrible battle of Solferino on 24 June was the result; an event which led to the foundation of the Red Cross by Henri Dunant. Before the war, the k.k. Commission apparently had enough leisure time to visit the cave and was obviously important enough to be allowed into the gated Erzherzog Johann Gallery.

The last inscription $70 \mathrm{~cm}$ to the right of the main panel (one line, $8 \times 1 \mathrm{~cm}$ ) is the best preserved and reads: "Mallner 23.II.1861". This name could be identical with a certain Mallnar, who was reportedly present when Luka Čeč discovered the new passages (Schmidl, 1854, p. 1; Widmar called him "Insasse von Adelsberg mit dem Vulgar-Namen Mallnar").

These inscriptions span several decades, and show that the frequency of visits was most probably very low in the early days of the show cave since enough other passages were available to the cave explorer.

\section{FURTHER INSCRIPTIONS IN PISANI ROV}

The next group of inscriptions is found in the side passage to the east of survey point V. Here a group of explorers left their names on 28 January 1926 on the flowstone of the left wall of the furthest chamber.

Another group of inscriptions is found on the wall above the footpath where it dips below a low arch and disappears behind a breakdown block (north of PJ survey station XI; Fig. 9). Seven inscriptions are found here, mostly modern. Only a large, black "A.U." looks older. The name "Perko, Anton" (with an illegible date) is, however, worth mentioning. He was one of the original members of the "Hades-Club", a student cavers' organisation from Trieste founded in 1893 (Hofmann-Montanus \& Petritsch, 1952). His brother, Ivan Andrej Perko (or in Italian G.A. Perco) (1875-1941), was the first president of the club and later became, due to his interest in caving, director of Postojnska jama and established the present Karst Research Institute. His name is found in Rov brez imena, signed 1892, one year before "Hades" was founded (Fig. 10). At that time he must have been sixteen!

After ten metres, to the left of the path a large dark red inscription is found reading "Pihounig, Mattio" (Fig. 11). Two more names appear to have been on the wall, both written with a blue copy pen. Below is a cross marked in black, a sign we have seen in at least two other places in the passage.

Nearby is "Hauer 6. May 1836" (Fig. 12). The " $\mathrm{H}$ " is written in such a way as to suggest a "J" being incorporated into the first vertical line of the " $\mathrm{H}$ ". The first name may therefore have started 
with a "J", like "Johann" or "Josef". It was usual to write the "i" as the "ÿ" in $19^{\text {th }}$ century German as seen here in the spelling of the month. A,Hauer" is, however, not on record as having visited the cave on that date (pers. com. Mrs. M. Kranjc). Martel (1894, p.436) mentions a Hauer, who worked with Hochstetter on the regional geology. This must have been Franz Ritter von Hauer (1822-1899), an eminent Austrian geologist who eventually became Director of the k.k. Geologischen Reichsanstalt (Imperial Geological Survey) in Vienna. His father was Joseph von Hauer (1778-1863), also a high ranking administrator, and a palaeontologist. He could have visited the cave in 1836, and was high enough in the hierarchy to be allowed into the newly discovered inner parts of the Erzherzog-Johann Grotte. (Dates according to: http://17.1911encyclopedia.org/H/HA/HAUER.htm).

\section{CONCLUSIONS}

The inscriptions of Postojnska jama form a rich historic material, as yet only partly analysed (Volpi, 1821; Hohenwart, 1832b; Shaw, 1992; Kempe, 2003). Here we looked at those of the Pisani rov which contains only a few names. The most remarkable site is a prominent column not far from the entrance to the passage which carries the names of all of the three most important early explorers, i.e. those of v. Löwengreif, Schaffenrath and Hohenwart. This may well be the only place in the cave where they can be found together. In the Old Cave Löwengreif and Schaffenrath also left their names, but separately. An inscription by Hohenwart was not noticed as yet (Kempe, 2003). These inscriptions predate the discovery of the back part of this cave in 1832 and the visit of Erzherzog Johann on 31 June 1832. It could have been expected that the Erzherzog was requested to leave his signature on the column or elsewhere in this cave, similar to that of Marie Luise, daughter of Franz I and wife of Napoleon I, who inscribed her name on the top of the Calvary Mountain on 4 June 1830 (Hohenwart, 1832b). However, nothing like this is mentioned by Schaffenrath (1834); nor did we find such a signature. Schaffenrath (1834) does not even mention the inscription column itself even though he was the first to leave his name there. A second - albeit scientific - celebrity visited Pisani rov, Éduard-Alfred Martel who in 1893 inspected the relation of the Erzherzog Johann Grotte to the Jeršanova dolina, and who made a longitudinal sketch of the passage (Martel, 1894; plate at p. 28). Chances of finding his signature are, however, very slight since so far only two Martel inscriptions are known, one recently discovered in Hovey's Cathedral in Mammoth Cave, Kentucky, and one from Aven Armand (Kliebhahn, 2003).

It will be interesting to compare the various inscriptions of Schaffenrath, Löwengreif, Hohenwart and others from elsewhere in the cave, in order to place them into the historic context of the discovery of the cave. Specifically dates of the years 1819 and 1820 would be of high interest.

\section{ACKNOWLEDGEMENTS}

We thank Dr. Tadej Slabe for organising the visit, and the administration of Postojnska jama for allowing us into the cave beyond the tourist trails. We also thank Mrs. Maja Kranjc, the librarian of the Karst Research Institute, Postojna, for checking some of the names and for providing us with citations. H. Süß, Linz, helped with the inscription written in Current handwriting. Leon, Jury and Roman accompanied us to the cave and got cold feet watching us investigating damaged speleothems, our main project during the visits 1 - 9 March 2004. 


\section{REFERENCES}

Bronn, H.C. 1826: Briefe aus der Schweiz, Italien und Südfrankreich im Sommer 1824. - Heidelberg, 652 pp., 4 Lithographs.

Habe, F., 1968: Luka Čeč, odkritelj Postojnske jame.- 150 Postojnske jame, 1818-1868, 9-17, Postojna.

Habe, F., 1986: The Postojna Caves. - Postojna, 82 pp., plates, 1 map.

Hofmann-Montanus, H. \& Petritsch, F., 1952: Die Welt ohne Licht, Höhlenforscher und Höhlengänger in Tragödien und Abenteuern. - J. Habel, Regensburg 346 pp, plates.

Hohenwart, F. Graf von, 1830, 1832a, 1832b: Wegweiser für die Wanderer in der berühmten Adelsberger und Kronprinz Ferdinands-Grotte bey Adelsberg in Krain; als Erklärung der von Herrn Aloys Schaffenrath, k.k. Kreis-Ingenieur in Adelsberg, gezeichneten Ansichten dieser Grotte. - Wien, J.P. Sollinger, 3 Vol., $16+9+14$ pp. and 21 copperplates (Reprint 1978: Šajn, S., ed.; Introduction: Habe, F. \& Šlenc, J.: Postojnska jama; 1. ed., Postojnska Jama THO; Postojna; 32 pp Introduction, folio).

Kempe, S., 2003: Die alten Inschriften der Adelsberger Grotte /Postojnska Jama. - Die Höhle, 54(2): 36-44.

Kempe, S. \& Henschel, H.-V., 2004: Alois Schaffenraths „zerbrochene Pyramide“ (Postojnska jama), ein Zeuge glazialer Höhlenvereisung? - Mitt. Verb. dt. Höhlen- u. Karstforscher, (50)3: 76-81.

Kliebhan, B., 2003: Eine Inschrift von Edouard-Alfred Martel aus dem Jahre 1912 in der Mammoth Cave (Kentucky) entdeckt. - Die Höhle, 54(4): 98-104.

Martel, É.-A., 1894: Les Abîmes, les eaux souterraines, le cavernes, les sources, la spéléologie. - Librairie Charles Delagrave, Paris, 578 pp. (Laffitte Reprints, Marseille 1996)

Schaffenrath, A., 1834: Beschreibung der berühmten Grotte bei Adelsberg in Krain. - I. Edlen v. Kleinmayr, Laibach, 32 pp., 2 Lithographs.

Schmidl, A., 1854: Die Grotten und Höhlen von Adelsberg, Lueg, Planina und Laas, Text and Atlas. - Wilhelm Braumüller, Wien, 316 pp, 15 Plates.

Schmidl, A., 1858: Wegweiser in die Adelsberger Grotte und die benachbarten Höhlen des Karstes. - 2. Aufl., C. Gerold's Sohn, Wien, 93 pp., 3 lithogr. Fig.

Shaw, T.R., 1992: History of Cave Science, the Exploration and Study of Limestone Caves, to 1900. - 2nd ed., Sydney Speleological Soc., Broadway, New South Wales, Australia, 338 pp.

Shaw, T., \& Čuk, A., 2002: Royal and other noble visitors to Postojnska jama 1819 - 1945. - Acta Carsologica 31(1) (Suppl. 1):106 pp.

Volpi, G. de, 1821: Über ein bey Adelsberg neuentdecktes Paläotherium. - Maldinische Schriften, Triest, 31 pp., 2 Plates. 